\title{
Autologous CD138-specific CAR T-cells
}

National Cancer Institute

\section{Source}

National Cancer Institute. Autologous CD138-specific CAR T-cells. NCI Thesaurus. Code C162482.

A preparation of autologous T-lymphocytes that have been eng ineered to express a chimeric antigen receptor (CAR) specific for syndecan-1 (CD138), with potential immunomodulating and antineoplastic activities. Upon administration, the autologous CD138 CAR-expressing T-cells target and induce selective toxicity in syndecan-1expressing tumor cells. Syndecan-1, a type 1 transmembrane proteoglycan and tumorassociated antigen (TAA), is overexpressed in a variety of cancer cells and plays a key role in the regulation of cell growth, differentiation, and adhesion. 